八發育稍、不良ノ如ク思ハレマフ。

5. 本異常咬頭結節八 Carabelli 氏結節卜

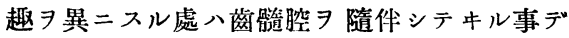
アリマス。

6. 本異常咬頭 有スル萄牙 7 發見シタ際 八速二保存的處置ヨ講ズル必要がアリマス。

7. 本咬頭ノ發現原因、不明デスが其ノ發 現部位,關係カラ考察シマス二煩側三角隆線 二出現スルモノカラ漸次中央溝二出現スルモ ノ二移行スル移行型卜思ヒマス。

終リ臨ミ貴重ナル標本 7 御貸與下サイマシ タ大阪齒科醫學專門學校小野郄授二深謝致 シ マス。

\section{追 加}

弓 倉 繁 家

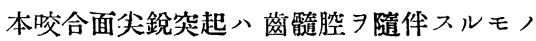
デ其ノ先端が少シカケタモノデ夫ョリ細菌ノ 感染 7 來シ壞瘨トナリ終二局所性骨膜骨髓炎 ヨ來シタ例(田淵) ヨ持ッテ 如キ突起 7 見タルトキハ將來二來ル危險性 考人，一定）方法(例人 バ齒髓摘出，根管充塡 等) ニョリ處置スルハ必要ナルコトデアルコ トヨー言致シマス。

\section{7.「ラッテ」ノ白㤠質發生ニ就テ}

\section{森 本 賢 市(東高齒)}

「ラッテ」ノ臼齒ニッキテ生後 5 日目ョリ各 5 日目每二 70 日二至ル迄ノ標本二就キテ其, 第一次白型質，第二次白垔質，發生狀態 $\exists$ 檢 索セり。此ノ標本二於テハ其，臼畺ノ發育狀 態八上顎，下顎大略同樣ニシテ第一，第二， 臼齒八各時期略? 相似タル所見ニシテ第三曰 齿八稍:逮延セルラ認么。郎生後 10 日目頃二 於テ第一四蒛二第一次白型質, 出現セル 認 メ，25日目頃二至りテ第一，第二曰蒛二第二 次白琶質ノ出現 7 認么。第三日齒二於テハ 30 日 ヨ 35 日頃二至リテ初メテ，第二次白垔質 出現シ來ルモ, 如シ。而シテ第一次白型質 八蓠頸部二近キ程著明ニアラハレ第二次白留: 質, 存不ル部位二至リテ左程著明ナラザルモ ノアリ。又然ラザルモノアリ。第二次白瑟質 八齒牙, 長軸二平行, 方向, 切片二於テハ根
端部及ビ根ノ屈曲セル部分二厚ク認メラレ横 锱標本二於テハ長徑，兩端部二厚ク生ゼル 見ル。第二次白瑟質八幼若ナルモノ程其ノ細 胞少數ニシテ形モ圓形二近シ。

\section{8. 顎及ビ齒龈ノ神經分布狀態}

藤 田恒太郎(東京高齒)

演者八昨年夏ヨリ本年初頭二互リ伯林大學 解剖學㜞室及ビ同齒科學敎室二於テ故 Prof. Dieck ト共同デ表題二示セル如キ研究ヨナシ 及。本研究八人及ビ犬 犬材料トシテ肉眼的方 法ヨ以テ行ツタモノデ，ソノ成績八大略次, 通リデアル。

1. 顎骨內二於ヶル神經，分布狀態八從來 ノ教科書二於ヶル 記載卜ハ可成り其ノ趣 ニセル所がアル(幻燈ニョリ示說)。

2. Bochdalek 氏, Ggl. supramax. 及ビ Zahnfächerganglien, 站 $ヒ ゙=$ Valentin 氏， Ggl. supramax. post. 八存在シナイ。

3. N. alveol. inf. 八第三大田蓠 , 後方 $=$ 向フ恒常性枝 7 出 retromolaris ト命名セント欲ス。

4. 所謂 Plexus dentalis inf. 八從來二樣 二記載セラレテ居ルガ, 之八 Canalis mandib.

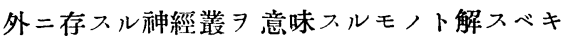
デアル。

5. 䕬眼八從來顎骨內, Nn. alveol. supp. 及ビ N. alveol. inf. 八枝ナル Rr. gingivales ヨリ支配セラルト信ゼラレテ居タガ，少クト モ肉眼的檢索, 結果デハ N. palat. ant., $\mathrm{N}$. infraorb., N. ment. 等顎骨外 ニアル神經ノ末 梢ヨリ支配七ラル。

\section{9. 日本「モグラ」ノ齒式ニ就テ}

$$
\text { 所 敏 一(日齒專) }
$$

「モグラ」ハ，食蟲目中最モ普通二見ラレル モノデアッテ，「モグラ」科「モグラ」亞科二屬 スル。歐羅巴「モグラ」TaJpa europaea 及ビ日 本「モグラ」Mogera wogura が可成り詳細二 記載セラレテ居ルが，然シ，Mogera wogura ノ蒛牙ノ形態學的研究報告八察々タルモノデ アル。動物站二爾科，學會二於テ公認セラレ 